\title{
Nyt om Gammelgård på Als
}

\section{Et kritisk bidrag til slottets bygningshistorie}

\section{Af Jorgen Paulsen}

Herregården Gammelgårds omfattende bygningskompleks på Als blev opført af hertug Hans den Yngre omkring 1600 og nedbrudt først i 1700-årene. Fhv. museumsdirekter Jørgen Paulsen har forsøgt at rekonstruere slottets oprindelige udseende og udbygningen fra 1665. Denne påvisning af slottets bygningshistorie afviger stærkt fra den hidtidige opfattelse, som blev fremlagt af Peter Kr. Iversen i Sønderjyske Årbøger i 1949.

\section{Indledning}

Det er nu mange år siden, Peter Kr. Iversen, Aabenraa, skrev en afhandling i Sønderjydske Årbøger om Gammelgårds godshistorie'. I et mindre afsnit, kaldet "Slot og avlsbygninger« kom han her også med en kortere redegørelse for herregårdens bygningshistorie. Det skete naturligt nok på grundlag af hans samtidige forelæggelse af en større samling bygningstegninger fra Gammelgård, opbevaret i Landsarkivet i Aabenraa ${ }^{2}$. Den omfatter ud over et amatøragtigt blyantsprospekt af herregårdens samlede kompleks af bygninger, set fra nord i det bakkerige midtalsiske landskab mellem Ketting og Asserballe, tillige en række mere eller mindre professionelt udførte rødkridts- og blyantstegninger af enkeltbygninger, såvel avlsbygninger, som hovedbygningen - med rette kaldet slottet, fordi Gammelgård i tiden 1626-1667 var de sønderborgske hertuginders enkesæde. Det drejer sig om både facader og grundplaner. Alt $\mathrm{i}$ alt er der tale om et særdeles interessant og for sin tid tillige såre sjældent materiale til konkret viden om Gammelgårds længst forsvundne bygninger.

Peter Kr.Iversen begrænser sin udnyttelse af disse tegninger til en kort beskrivelse af, hvad de efter hans mening kan fortalle om slottets udseende og indretning i 1600-årene. Han daterer dem til »sidste halvdel af det 17. århundrede«, men i billedunderskrifterne udvider han dette til »17. århundrede«, altså til også at omfatte hertug Hans den Yngres tid og dermed slottets oprindelige udseende og indretning.

Ud fra både tidsmæssige og stilhistoriske kriterier har det længe været min opfattelse, at en række af de af ham på dette grundlag fremførte synspunkter ikke kan være rigtige. Dette er baggrunden for det efterfølgende "kritiske» bidrag til Gammelgård slots bygningshistorie. Den direkte tilskyndelse til at tage denne opgave op nu er imidlertid et for nylig afsluttet arbejde med et 
hidtil ukendt håndtegnet og farvelagt landkort over Als og Sundeved ${ }^{3}$, hvorpå der forekommer en afbildning af slottet, som er væsentlig forskellig fra de i Peter Kr.Iversens afhandling gengivne skitseagtige løshåndstegninger i rødkridt af dets to facader. Denne forskel må der kunne findes en forklaring på.

Landkortet er signeret og dateret af en ikke identificeret korttegner ved navn Henrich Ottendorff 1655 . Forlægget har været et andet håndtegnet landkort, som er udført af vor berømte landsmand, kartografen og matematikeren Johannes Mejer fra Husum. Henrich Ottendorffs kort er særpræget derved, at han i stedet for signaturer har anvendt bitte små miniaturetegninger af landsbygårde og -huse, kirker, slotte og herregårde m.m., hvilket bidrager til en mere visuel belysning af landskabets udseende, end signaturer formår at give. Initiativtageren til dette landkort, der har en tydelig hertugelig-sønderborgsk og -nordborgsk baggrund, er efter alt at dømme hofmesteren hos hertug Hans Christian af Sønderborg (1607-53), nemlig en adelsmand af mecklenburgsk herkomst ved navn Frederik Lützow, som i 1645 blev gift ind ved det nordborgske hof med den daværende hertugindes kammerjomfru for tre år senere - i 1648 - at blive udnavnt til hofmester hos hertugen i Sønderborg med bolig på slottet dér. Dette nævnes, fordi han i kraft af sin stilling må have kendt hertugens ægtefælle Anna, der ved hertugens død 1653 fik Gammelgård som sit enkesæde, og hendes slot dér særdeles godt, og dette forhold må bidrage til styrkelse af tiltroen til landkortets afbildning. Den fremstiller slottet, set fra syd (fig. 1). Ved første øjekast opfattes bygningen som et trefløjet anlæg omkring en åben slotsplads ud mod en bred voldgrav, der ved sine krumninger på hjørnerne antydes at have omgivet hele det voldsted, hvorpå slottet var opført. Både midterbygningen og de to fremspringende sidebygninger med antydede renæssancegavle står $\mathrm{i}$ to stokværk og med sadeltag.

Ser man imidlertid nøje efter og lader blikket følge sidefløjenes taglinier bagud, bliver det indlysende, at disse er gennemgående og fremspringende mod syd ligeså vel som mod nord. Fra tegnerens side må det være bevidst, at slottet er vist som set en smule fra oven for derved at fremhæve bygningens specielle symmetriske form, altså som bestående af en midterbygning mellem to gennemgående sidefløje af en sådan længde, at de på begge ender omslutter en rektangulær forgård eller slotsplads, der er åben ud imod voldgraven.

De to i vor sammenhæng væsentligste oplysninger, der kan udledes af denne afbildning på landkortet fra 1655 - ti år før slottets udvidelse og på et tidspunkt, hvor bygningen endnu stod i sin oprindelige skikkelse, således som det var opført under Hans den Yngre omkring 1600 - er for det første dets arkitektoniske type eller form en $\mathrm{H}$ formet bygning - for det andet, at der var tale om et hus i to stokværk og med sadeltag.

Lad der så derudover være detaljer, der ikke er helt rigtige. Sådanne skal 
sådanne spir også er vist på dette landkorts tre andre billeder af hertugelige slotte, nemlig Sønderborg, Nordborg og Østerholm. De kan måske derfor forklares som tegnerens bevidste markering af netop disse fire slottes status som hertugelig residens.

Endelig forekommer det direkte fejlagtigt, at den østlige sidefløj på afbildningen fremtræder bredere - med tre vinduesfag i gavlen - end dens pendant vestfløjen. Dette ville være et brud på renæssancestilens forkærlighed for symmetri.

Men tilbage til det væsentlige, nemlig bygningsformen - en midterbygning mellem to gennemgående sidefløje. En sådan er for den tids vedkommende sjælden, for ikke at sige enestående, under vore himmelstrøg. Ikke desto mindre synes det, som om den har været særlig yndet af Hans den Yngre i tiårene omkring 1600. I hvert fald opførte han 1594-1601 det store slot Ahrensbök, beliggende ca. $20 \mathrm{~km}$ nordvest for Lübeck, som en bred midterbygning mellem to sidefløje af forskellig længde på dens to sider ${ }^{4}$. Også Nordborg slot, bygget omkring år 1600 oven på ruinerne af den da næsten forsvundne middelalderborg som en bindingsværksbygning, skal have været af samme type, her dog med ganske korte, nærmest risalitagtige ender på sidefløjene og med bevarelse af det middelalderlige kærnetårn midt på hovedbygningens facade. Nordborg blev desværre fuldkommen ødelagt ved en voldsom ildebrand i 1665 .

\section{Hans den Yngres slot ca. 1600. Første byggefase}

Hovedbygningen eller slottet på Gammelgård blev opført i bindingsværk på et ved den middelalderlige gård nærliggende voldsted af størrelsen ca. $20 \times 30$ $\mathrm{m}$. Den $\mathrm{i}$ indledningen omtalte samling af bygningstegninger indeholder bl.a. et helt sæt af professionelt udførte bygmestertegninger, bestående af fire eksteriører, der viser slottet set fra dets fire sider - nord, syd, øst og vest - samt fire dertil svarende og i samme målestok udførte grundplaner. Disse er desværre hverken omtalt eller gengivet i Peter Kr.Iversens afhandling, om end de forekommer langt mere oplysende om bygningens arkitektur i enkeltheder end de af ham gengivne rødkridtstegninger. Efter min opfattelse er det muligt at datere tegningerne, idet de må anses som bygmesterens (arkitektens) forarbejder til den af hertuginde Anna ønskede udvidelse, som er omtalt i Ketting sogns kirkebog og ifølge denne fandt sted i første halvår af 1665 . De er således fra en langt senere tid end slottets oprindelse, men da de må være tegnet på grundlag af og med det oprindelige bygningsværks udseende og indretning som udgangspunkt, og det tilsyneladende af en særdeles kyndig bygmester 
med godt kendskab til dettes stil, vil de efter mit skøn kunne anvendes med held $\mathrm{i}$ et forsøg på at rekonstruere det oprindelige slot, $\mathrm{i}$ særdeleshed når de jæunføres med de oplysninger, som landkortets afbildning allerede har givet.

Når det gælder bygningsformen, vil det være mest naturligt at tage grundplanen som udgangspunkt (fig.2). Af denne fremgår, at hovedindgangen til huset var gennem et mangekantet tårn i det sydøstre hjørne af den nordre slotsgård. En vindeltrappe i tårnet førte dels op til førstesalen, dels ned til kælderetagen. I stueetagen førte en dør ind til midterbygningen, der var opdelt $i$ to større rum, først en forhal (A) og til højre for denne et stort gemak (B). Disse to rum var dele af midterbygningen, hvis endevægge til begge sider var bygget et stykke (ca. $1 \mathrm{~m}$ ) ind i sidefløjene. Midt på disse endevægge var der en stor kamin.

I hvert af midterbygningens fire hjørner førte en dør ind til de fire gavlgemakker i sidefløjene ( $\mathrm{C}$ og $\mathrm{E}, \mathrm{I}$ og $\mathrm{M})$, der alle havde kamin midt på gavlvæggen. Det nordre gavlgemak i den østre sidefløj (C) var lidt mindre end de øvrige,

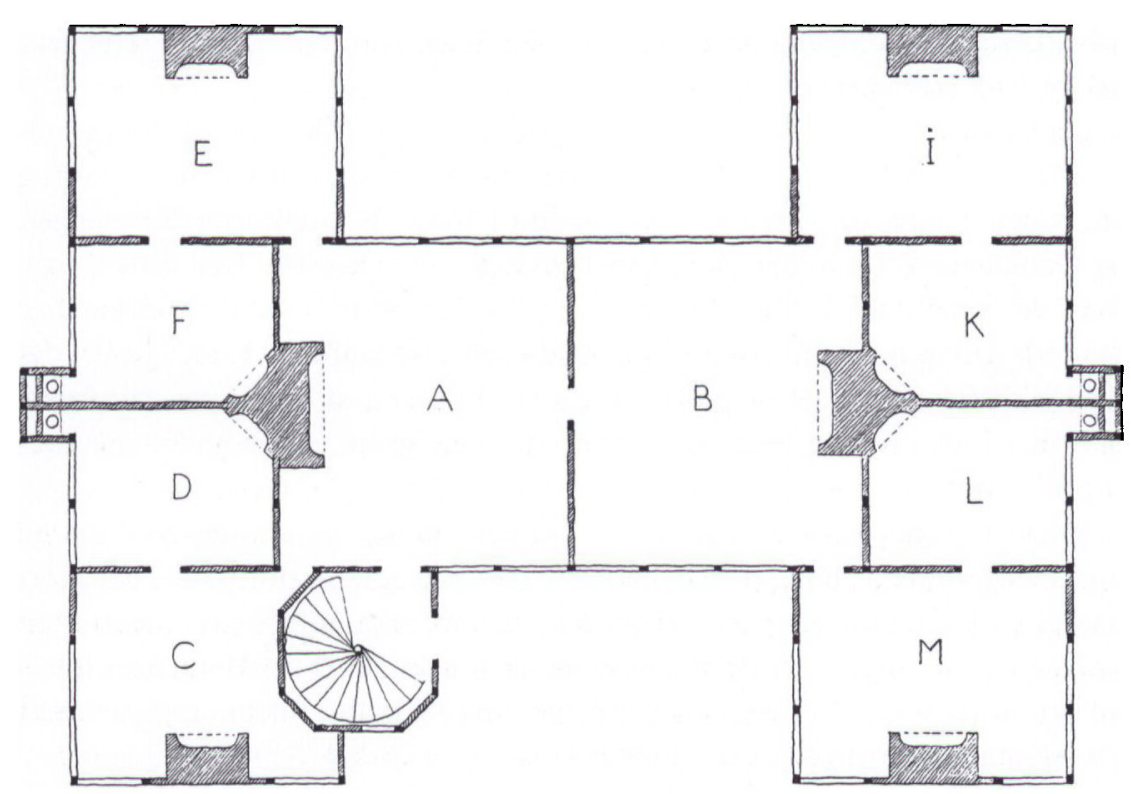

Fig. 2. Grundplan af slottets 1 . stokvark i den oprindelige form. Rekonstrueret pd grundlag af blyantstegning fra 1665 ved fraklipning af den da opforte tilbygning til midterbygningen (jvf. fig. 6). Bogstaverne henviser til de enkelte rums anvendelse, som er anfort pa tysk: A. Forstue med kamin, B. Stort gemak, C. Gemak $i$ sideflojen med kamin, D. Kammer med kamin, E. Gavlgemak med kamin, F. Kammer med kamin, I. Gavlgemak med kamin, K. Kammer med kamin, L. Kammer med kamin, M. Gavlgemak med kamin. Den $i$ alle henseender korrekte tegning er udfort af arkitekt Soren Lundquist, Hillered. 
idet trappetårnet for en del var bygget ind i det. Fra hvert af gavlgemakkerne førte en dør i bagvæggen ind til et mindre kammer ( $D$ og F, K og L), der alle havde en lille hjørnekamin ind imod midterbygningens to store kaminer på endevæggene, med hvilke de således havde fælles røgkanal og skorsten. I hvert af de fire små kamre var der i ydervæggen en dør ind til en såkaldt "hemmelighed " (kloset), anbragt parvis (to og to) $\mathrm{i}$ en mindre, rektangulær udbygning midt på ydermurene, hvorfra der var nedløbsrør til voldgraven omkring bygningen.

Grundplanen for 2. stokværks (førstesalens) vedkommende var nøjagtig den samme som stueetagens, og det både i midterbygningen og sidefløjene. Det vil sige, at der i huset var fire større lokaler - forstue og tre større gemakker til fælles selskabeligt brug samt otte små ens to-værelsers suiter, alle udstyret med datidens moderne bekvemmeligheder hvad angår varme- og toiletmuligheder. Denne indretning forekommer yderst rationel og fleksibel for et mindre landslot, beregnet til kortere landophold for dels medlemmer af, dels eventuelle gæster hos den hertugelige familie, der havde fast bolig på det nærliggende store slot i Sønderborg. Sådan blev slottet bygget i Hans den Yngres tid efter alle kunstens regler som et herskabshus, $i$ hvilket tjenerskab var henvist til arbejde og ophold $\mathrm{i}$ den rummelige kælderetage. Der var nemlig fra begyndelsen kælder under hele huset.

Undersøgelsen af slottets oprindelige grundplan gav således et positivt resultat. Den bekræftede, at sådan må huset have været indrettet under hertug Hans den Yngre, og sådan stod det endnu i 1655, da landkortet blev tegnet, og Gammelgård for anden gang blev benyttet som enkesæde. Den viste tillige, hvor den senere udvidelse skete, nemlig på sydsiden op imod den oprindelige midterbygning med den søndre slotsplads som byggegrund. Endelig blev det med sikkerhed fastslået, at slottet må være bygget $i$ to omgange, den første omkring 1600 i hertug Hans den Yngres tid, den anden i 1665 under enkehertuginde Anna.

Efter at grundplanen ved at se bort fra den del, der ikke hører med til den oprindelige slotsbygning, dvs. bygningen over den søndre slotsplads, har gjort det klart, hvorledes det oprindelige slot var indrettet, gælder det herefter en nærmere undersøgelse af de fire eksteriørtegninger (fig.3-5). Hvad kan disse, ud fra de samme forudsætninger, der blev lagt til grund for undersøgelsen af grundplanerne, fortalle om slottets oprindelige udseende?

Da nordfacaden i sin helhed - med de to i forhold til midterbygningen fremspringende sidefløje omkring den nordre slotsplads - ikke blev berørt af det senere byggeri ud over midterbygningens forhøjelse med et nyt tredie stokværk, vil det være naturligt først at se nærmere på denne (fig.3). Ved fraklipning af denne etage på tegningen viser det sig let at nå frem til en 


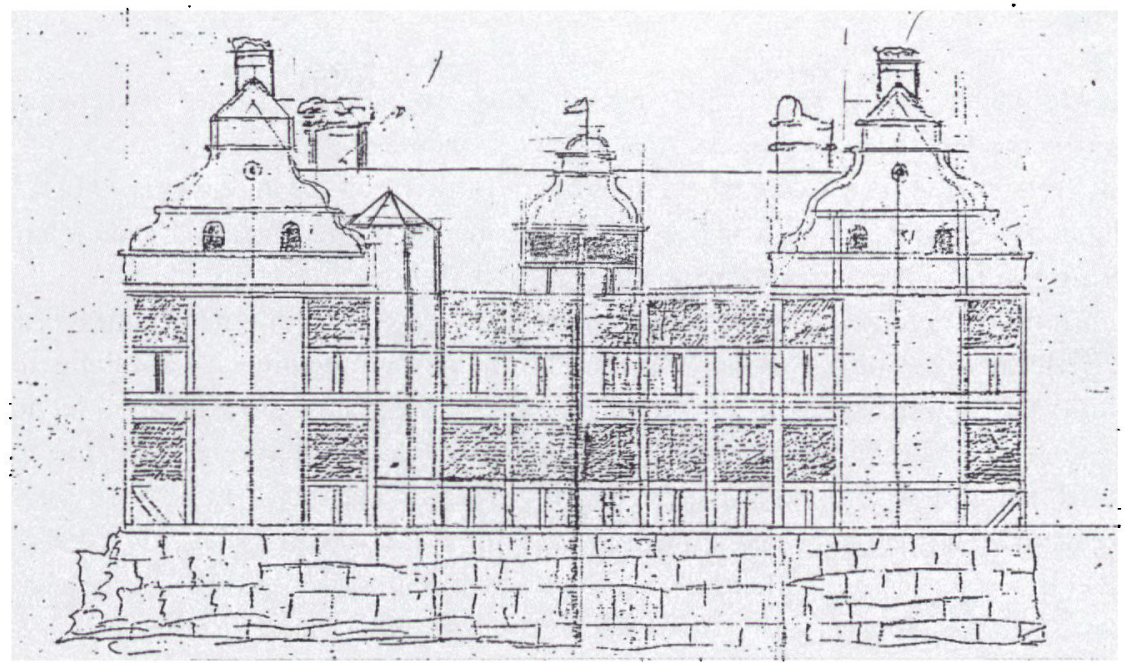

Fig. 3. Hans den Yngres slot. Facaden mod nord. Rekonstruktion pd̊ grundlag af bygningstegningen fra 1665 ved fraklipning af midterbygningens 3. stokverk samt påklistring af gavlkvisten og den overste del af indgangsto̊rnet (jfr. fig. 9).

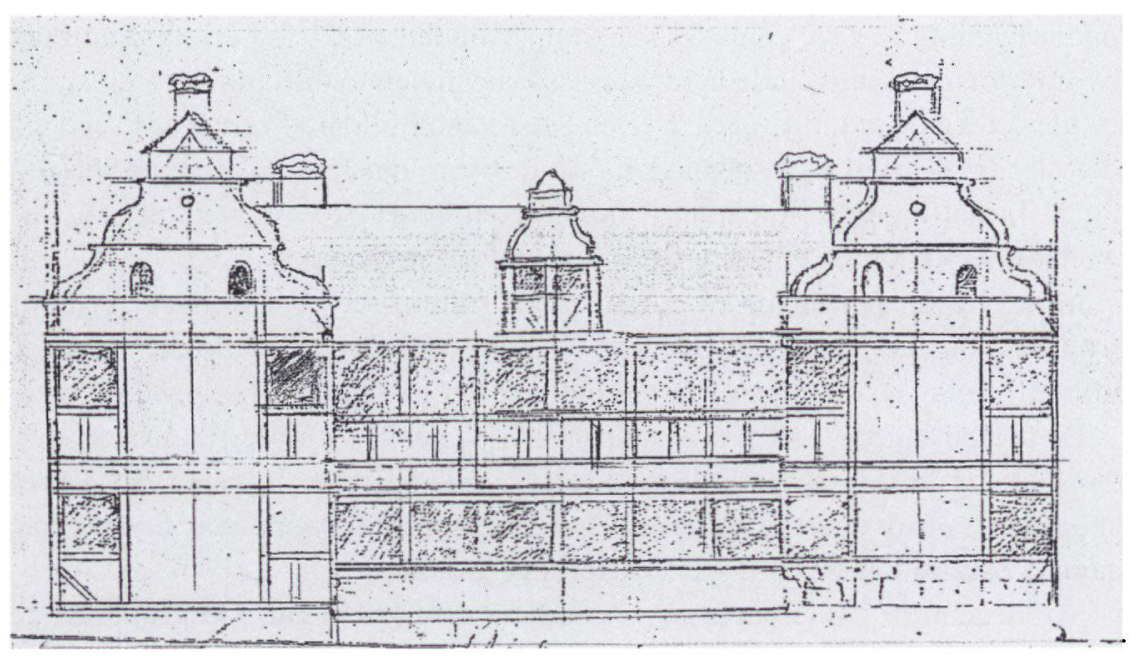

Fig.4. Sydfacaden af Hans den Yngres slot. Rekonstruktion som foregående (jvf. fig. 10), her med overklistring af gavlpartiets stueetage $i$ den vestre sideflej. 
tilforladelig rekonstruktion af denne facade, som den oprindelig må have set ud.

Det første der falder stærkt $\mathrm{i}$ øjnene er, at bygningen ud mod voldgraven på denne side hviler på en høj sokkel af store kampestenskvadre i 4-5 lag. Byggegrunden på voldstedet her har øjensynlig været noget usikker. Måske blev det en medvirkende årsag til bygningens hurtige forfald og endelige nedbrydning allerede i de forste årtier af 1700-årene.

Den omhyggeligt udforte facadetegning giver et godt grundlag for iagttagelse og vurdering af den fine regelbundne bindingsværksbygning i oprindelig to stokværk og med sadeltag. Slottet fremtræder som et helstøbt eksempel på en bygning $\mathrm{i}$ nederlandsk-nordisk renæssancestil, tydeligst markeret ved sine to sidefløjes i alt 4 fritliggende, prægtigt svungne gavlpartier, 2 mod nord og 2 mod syd. I højden er de ved vandrette sandstensbånd opdelt i 4 lag af forskellig bredde og øverst oppe afsluttet med en spids trekant. I det næstnederste parti ses 2 rundbuede vinduer og midt i det overliggende et rundt uglehul.

Gavlmurenes underdele er $\mathrm{i}$ formen nøjagtig kvadratiske, med vinduer $\mathrm{i}$ begge etager anbragt foroven i de 4 hjørner. De murede tavl under vinduerne har dokker i midten, hjørnetavlet forneden dog skråbånd af stabiliseringshensyn $^{6}$. Midterpartiet mellem vinduesfagene er uden stolper, medens etagedelingen tydelig fremgår af remmen. Den i forhold til sidefløjene tilbagetrukne midterbygning $i$ to stokværk er ved stolper opdelt i seks fag ud mod gården, hvoraf dog det længst inde mod den østre sidefløj er skjult bag det fremspringende ottekantede indgangstårn. Den sidste, mindre del af tårnet ses ikke, da den var bygget ind i gavlgemakket, således som det fremgik af grundplanen fig. 2. Tårnet hævede sig i højden nøjagtig en etage op over taglinien og var øverst afdækket med et forholdsvis lavt, spidst hættetag.

Midterbygningen havde over midten en stilren, ret bred tofaget gavlkvist med rektangulær underdel og lave vinduer over tavl med dokke. I begge midterbygningens to etager sad vinduerne $i$ tat række over tavl med dokker.

På tagene ragede $\mathrm{i}$ alt 6 skorstenspiber op, nemlig 2 store på midtertaget, forskudt ud til siderne på linie med sidefløjenes inderste stolpefag, altså med skorstene opført over de to store kaminer på midterbygningens endevægge, samt 4 mindre bag hver af gavlspidsernes trekanter.

Sydfacaden (fig.4) er rekonstrueret ud fra det, der fremgår af grundplanen (fig.2), nemlig at de to gavlfacader var fuldkommen symmetriske. Dog var midterbygningens gavlkvist her smallere end på nordsiden.

Med hensyn til begge disse kviste er der ved rekonstruktionsforsøgene gået ud fra, at de ved det senere byggeri i 1665 må være ført med op i deres originale former ved brug af både de svungne og vandrette sandstenskarme og -bånd. 
Sidefløjenes gavlpartier mod syd fremtrådte oprindeligt som fritliggende og helt som de to mod nord. Dog ses det, at den østre her mod syd hvilede på et lavt, to lags fundament af tilhugne kvadre.

Et forsøg på at rekonstruere de to sidefløjes ydermure vil bedst kunne baseres på bygmesterens tegning af den vestre (fig.5), idet denne også efter 1665 - med blot en enkelt lille ændring - stod bevaret helt $i$ den samme skikkelse, som den var blevet opført $i$ under Hans den Yngre omkring år 1600. Begge sidefløje må efter alt at dømme have været ens $\mathrm{i}$ opbygning og udformning. De var tidstypiske bindingsværkslænger i 2 stokværk med ialt 11 fag, nemlig 5 på hver side af et tydelig markeret, fremspringende midterfag med 3 højstolper og flere tværgående løsholte. Det drejer sig tydeligvis om den på grundplanen fig. 2 viste, smalle udbygning med »hemmelighederne«. Den havde øverst oppe eget tag.

De 5 fag på hver side af udbygningen havde i begge stokværk vinduerne placeret parvis - to og to - foroven og med et tavl imellem. Der var ingen dokker i tavlene, men skråbånd i hjørnerne og $i$ et enkelt andet tavl forneden. Midt over tagryggene ragede de store skorstenspiber fra midterbygningens tag, og på gavlenderne sad de mindre over kaminerne i gavlgemakkerne. På den søndre halvdel af vestfløjen var der endvidere et tagvindue.

Hermed er undersøgelsen af og forsøget på ved gengivelser af rekonstruktio-

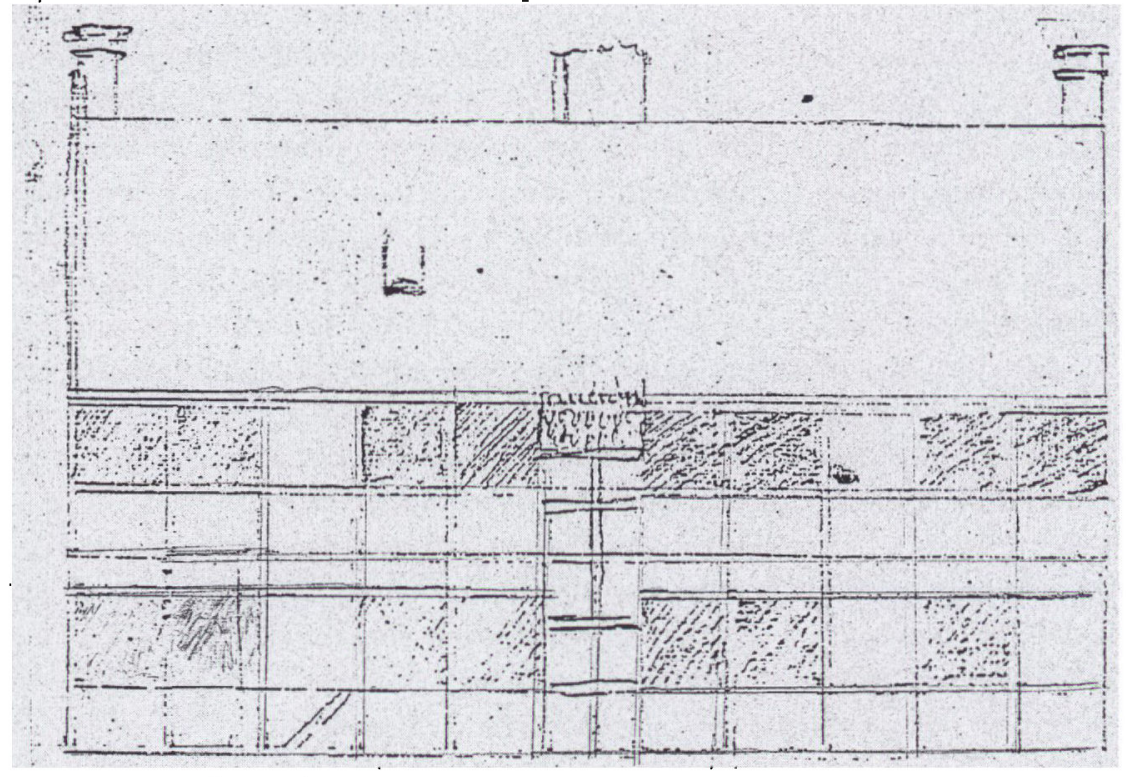

Fig.5. Vestre sidefløjs ydermur. Rekonstrueret efter bygmestertegning fra tiden efter 1665. 
ner, udført på grundlag af de foreliggende bygmestertegninger - såvel grundplaner som eksteriører fra 1665 - at vise, hvorledes Hans den Yngres slot må have set ud og været indrettet, ført til ende.

Det fremgår, at Gammelgårds hovedbygning var præget af en bemærkelsesværdig arkitektonisk kvalitet. I omfang var bygningen ret beskeden ${ }^{7}$, men på Als må den have været en virkelig pryd. Den var både $\mathrm{i}$ indretning og udseende præget af renæssancetidens fremherskende idealer om klarhed og ro, symmetri og harmoni.

Hans den Yngres slot var ikke - som beskrevet og gengivet i Peter Kr.Iversens afhandling s. 101-106»-en trefløjet bygning med hovedfløjen mod syd, strækkende sig øst-vest -«, og der var heller ikke - som anført - i denne nogen kirke ud mod syd. Sådan blev det først efter en større udvidelse i form af en tilbygning til og forhøjelse af den oprindelige midterbygning, således som der i enkeltheder vil blive gjort rede for i det efterfølgende afsnit.

\section{Udvidelsen under enkehertuginde Anna i 1665. Anden byggefase.}

Efter hertug Hans Christians tidlige død i 1653 fik hans da 48-årige enke Anna Gammelgård til enkesæde. Som formynder for sin 12-årige søn, arvefølgeren Christian Adolf (1641-1702) tiltrådte hun samtidig regeringsmyndigheden i det lille hertugdømme Sønderborg. Foruden sønnen var der i ægteskabet to døtre i alderen 15 og 17 år. Under de ulykkelige krigsforhold i årene 1657-60 med gentagne angreb på og besættelse af såvel Sønderborg slot som øen Als, må Gammelgård ved sin beliggenhed og sine faciliteter som landbrugsbesiddelse have været et godt og givtigt opholds- og fristed for den hertugelige familie, om end pladsforholdene i det af hertug Hans den Yngre opførte landslot var ret begrænsede. Sådan må enkehertuginden nok have følt det allerede dengang og med alderen efterhånden mere og mere, som tiden gik og ønsket om mere hjælp i dagliglivets fornødenheder trængte sig på.

I hvert fald besluttede hun $i$ en alder af omkring 60 år at iværksætte et ret omfattende byggeri på slottet med det formål at skaffe mere plads til bl.a. bolig for en forvalterfamilie og endvidere til en kirkesal i selve huset, for ikke hver søndag at skulle køres til gudstjeneste i sognekirken i Ketting. Dateringen af dette byggearbejde skyldes sognepræsten, som nogle år senere - $\mathrm{i}$ anledning af enkehertugindens død - må have følt sig tilskyndet til i kirkebogen at indskrive nogle mindeord om sognets fornemste beboer.

Under "Anno 1668« beretter han først om hertuginde Annas dødsfald, der indtraf i Weimar d. 12. december under en rejse med besøg hos hendes datter 
og svigersøn ${ }^{8}$. Begravelsen foregik samme sted den 28.januar 1669. Derefter hedder det ordret $i$ kirkebogen om hertuginden: "Hun var god mod Tandslet kirke, hvor hun forærede en kalk og en disk. Til Asserballe gav hun et alterklæde. Men her til kirken gav hun aldrig intet [noget], hvortil hun [ellers] altid søgte her Guds hus [gik i kirke]'. Dog efter hendes død fik vi det skønne timeglas og det herlige krucifiks, som hænger på den højre side af væggen.« Derefter folger det som i denne sammenhæng er det væsentlige, nemlig om selve byggeriet: "Anno 1665 lod hun en egen kirke af tømmer og mursten opbygge på Gammelgård, som stod synder og nør [syd og nord] op ved krudgården [urtehaven] og lod den indvie (samme år derpå blev begyndt) $\mathrm{d}$. 26. Juli, St. ANNÆ Dag«. Denne beskrivelse af stedet, hvor tilbygningen med bl.a. kirkesalen blev opført er i nøje overensstemmelse med bygningstegningerne fra 1665 (se grundplan fig. 7, bogstav c). Men sådan har Peter Kr. Iversen ikke opfattet det. Ved alene at fokusere på kirken som formål for det byggeri, der omfattede meget andet, og ved fejlagtigt at henlægge den kirkesal i slottet, som blev indrettet i 1665, til Hans den Yngres tid, måtte han ty til den udvej at tolke det, der blev bygget i 1665 som en "særlig kirkebygning - en i sig selv ganske usandsynlig opfindelse ${ }^{10}$. Hvad skulle enkehertuginden dog med hele to kirker på Gammelgård, i særdeleshed når hun, som sognepræsten havde berettet, plejede at søge Guds hus i Ketting. Det var netop det besvær, hun $i$ sin efter datidens forhold høje alder, gerne ville slippe for ved at få indrettet en egen kirke $i$ sit hus. Dette onske fik hun opfyldt $i$ form af en kirkesal $\mathrm{i}$ en tilbygning på sydsiden af den oprindelige midterbygning. Desværre er den forkerte opfattelse om to kirker på Gammelgård uden videre godtaget og videreført i så vigtige bogværker som Danmarks Kirker og Trap Danmark ${ }^{1 !}$.

At det drejede sig om en kirkesal og ikke en særlig kirkebygning fremgår da også tydeligt af kirkebogens beretning om dennes videre skæbne. Den lyder: "Anno 1670. På Hans Kongel.Mayest. Kong Friedrichs den Tredies Nådigste bevilling blev samme kirke på Gammelgård opbrudt, og lod Hans Durch1[auchtighed] den Højbårne Herre Ernst Günther, Arving til Norge, Hertug til Sleswig Holstejn etc. den forflytte, opsætte, forfærdige og indvie på Augustenborg, hvor den nu står og [det] meget forbedret. Hvorlænge den der skal have varlighed. Veed Gud!«

At der ved denne flytning til Augustenborg slot et par år efter det sønderborgske hertugdømmes konkurs i november 1667 var tale om overførsel af et slotskapel, kan der ikke herske tvivl. Ernst Günther, den nye hertuglinies grundlægger, var svoger til den afdøde hertuginde Anna (som bror til hendes ægtefælle Hans Christian), så både han og hans gemalinde Augusta må have fået et ønske opfyldt, da kong Frederik III gav sin tilladelse til, at Gammel- 
gårds kirkesal måtte flyttes til det første Augustenborg slot som dettes slotskapel. Dette forblev jo derved både i familiens eje og beliggende i Ketting sogn, hvortil beboerne i Stavnsbøl og Sebbelev sognede. Hertug Ernst Günther fik i øvrigt ved samme lejlighed med visse forbehold overdraget patronatsretten til Ketting kirke ${ }^{12}$. En særlig kirkebygning har der aldrig været i flækken, derimod nok et slotskapel både i det første slot fra begyndelsen af 1662 og et helt nyindrettet $i$ det nuværende slot fra 1776, som imidlertid intet har med Gammelgårds kirkesal at gøre.

I kirkebogen berettede sognepræsten i Ketting alene om byggeriet af hertugindens »egen kirke«. Det var naturligt nok det, der vedrørte hans embedsområde, som havde hans særlige interesse. Hvad byggearbejdet i 1665 i øvrigt omfattede, skrev han intet om.

Den tilbygning \#af tømmer og mursten, som stod sønder og nør op ved krudgården « rummede nemlig adskilligt mere end kirkesalen i dennes 2 . stokværk og med vinduer ud mod haveområdet. Bygningen blev opført over hele den oprindelige søndre slotsplads - med facademuren endda lidt ud over denne - som tilbygning til den oprindelige midterbygning og det i hele tre stokværk over kælderen, altså et stokværk højere end den gamle del, som derfor også måtte forhøjes med en ny etage. Endelig blev den nye, herefter meget brede, sammenbyggede midterbygning forsynet med et nyt, næsten kvadratisk, højt valmtag, der på midten fik en skorstenspibe over den nye skorsten, som byggedes op fra kælder til kvist af hensyn til opvarmningen af de nye rum, herunder kirken på førstesalen.

Slotsbygningen som helhed kom herefter til at fremstå som et i stilmæssig henseende blandingsprodukt med de to af nybyggeriet så at sige uberørte sidefløje bevaret $i$ typisk renæssancestil og midterbygningen $i$ sin nye form præget af barokstilen, mest påtrængende ved dens højde, bredde og tyngde samt ved valmtaget, en typisk barok foreteelse.

For sydfacadens vedkommende fik tilbygningen den uheldige følge, at de to tidligere fritliggende søndre sidefløje blev klemt inde, hvorved deres høje, flotte gavlpartier mistede meget af deres tilsigtede virkning. Den oprindelige symmetri mellem nord- og sydfacaden blev ødelagt og hele den fine balance $\mathrm{i}$ det oprindelige bygningsanlæg blev forstyrret derved, at nybygningen forskubbede vægten over på sydsiden. I æstetisk og kunstnerisk henseende betød udvidelsen af slottet noget ubetinget negativt, i praktisk imidlertid det positive, at der blev mere plads og muligheder for en bedre udnyttelse af huset under andrede forhold.

Dette fremgår af de bygningstegninger - både grundplaner og eksteriører som den åbenbart meget habile bygmester udarbejdede i den forbindelse.

Grundplanen over 1. stokværk (fig.6) vidner om, at den enkle form i det 


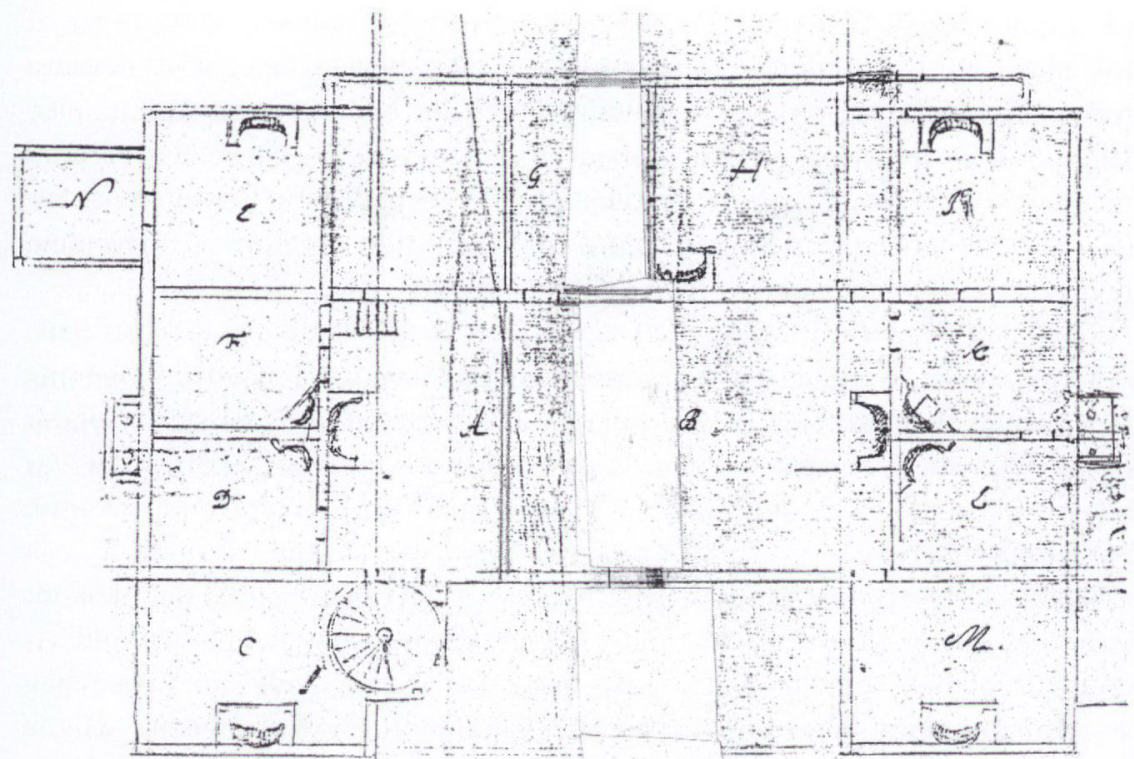

Fig.6. Grundplan af slottets 1 . stokvark efter opforelsen 1665 af en tilbygning til midterbygningen. Gengivelse af bygmestertegning. Bogstavbetegnelser: A. Forhal. B. Stort gemak. C. Flojgemak med kamin. D. Kammer med kamin. E. Gemak med kamin. F. Kammer med kamin. G. Spisekammer. $H$. Borne- og folkestue. J. Nu kokken. $K$. Nu forvalterens stue. L. Dito hans kammer. M. Logement $i$ flojen med kamin. N. Lille kabinet.

oprindelige slot (se fig.2) - en midterbygning mellem de gennemgående sidefløje - blev væsentlig ændret ved opførelsen af tilbygningen. Den blev ikke blot udvidet med en nybygning over den tidligere slotsplads, men nybygningens facademur blev på sydsiden skudt et lille stykke (ca. $1 \mathrm{~m}$ ) ud over sidefløjenes byggelinier og $\mathrm{i}$ forlængelse af den blev der op imod vestfløjens hidtil så smukke sydgavl opført en ca. $4 \mathrm{~m}$ lang og smal udbygning i stuehøjde som læskur for en dør ind til forvalterboligen. Dette skur tjente herefter dels som forstue, dels som opvaskehus nær ved køkkenet.

Endvidere fremgår det af grundplanen, at der på den østre sidefløjs ydermur, nær op ved dennes sydgavl er tilkommet en næsten kvadratisk udbygning. Om dennes udseende og formål vil der blive givet forklaring nedenfor under gennemgangen af østmurens udseende (se fig. 12).

Men nu til rumindretningen i slottet efter byggearbejdet i 1665. I såvel midterbygningens oprindelige del som $i$ de to sidefløje forblev denne uændret $i$ stueetagen (jvf. fig. 2 og fig.6), dog med undtagelse af, at der ved opforelse af en skillemur i østfløjens søndre gavlgemak blev etableret en korridor mellem dette og den nye tilbygning, således at man fra denne fik mulighed for passage 
til slottets forhal. Ifølge grundplanen kom forvalterboligen til at bestå af følgende rum: I tilbygningen først et kammer uden bogstavbetegnelse; dernæst spisekammer (G) og ved siden af dette en såkaldt børne- og tyendestue med kamin (H). I den vestre sidefløj endvidere det søndre gavlgemak, der herefter blev køkken (I) med kaminen som ildsted; ved siden af dette forvalterens stue (K) og kammer (L) begge med hjørnekaminer, samt det nordre gavlgemak, nu kaldet »logement i gavlen med kamin« (M).

For 2. stokværk (fig.7) gælder det samme som for 1., nemlig, at dispositionen af rummene i de oprindelige bygningsdele forblev som for. I den nye tilbygning blev dennes førstesal i sin helhed optaget af kirkesalen (c), som stod "sønder og nør op ved krudgården «, dvs. med vinduer i sydmuren, hvorfra der var udsigt over nyttehaven. Kirkesalen blev opvarmet ved en nyopført stor kamin på dennes nordvæg.

Det 3. stokværk (fig. 8) var helt igennem nyt. Over den gamle del blev der indrettet en stor sal (a) med kamin og i tilbygningen bag denne henholdsvis et større gemak (b), der måtte nøjes med den varme, som skorstenen bag storesalens kamin kunne afgive, og et lille kammer (c). Loftsrummene (d) i de $\mathrm{nu} i$ forhold til den høje midterbygning lave sidefløje betegnes som meget lavloftede.

Endelig er der grundplanen over kælderetagen. Den er interessant også derved, at en stiplet linie omkring hele bygningsanlægget angiver voldstedets størrelse og dermed bygningens beliggenhed ud til voldgraven.

De oplysninger, grundplanen i øvrigt giver om kælderens indretning, er begrænsede, idet blot rummene i østfløjen og en del af den nye tilbygning er anført. I østfløjen var der fra begyndelsen under det nordre gavlgemak vinkalder (A), hvis hvælvede loft angives at være faldet helt ned, samt mælkekælder med bjælkeloft og brygkælder (C), hvis hvælvede loft nogle steder ligeledes var faldet ned. Bryggekedlen ses opbygget her midt på gavlvæggen og med indfyring fra et siderum.

Under tilbygningen er anført dels en lille kælder med bjælkeloft (D) og en ølkælder, om hvilken det hedder: wist nah mit Kampfsteine aus dem wasser auf gesetzt, ist aber etlicher wegen schon eingefallen und 3 Ellen hoch«, hvilket vel må sige, at den - skønt opsat med kampesten nær ud til vandet i voldgraven - allerede var faldet ind nogle steder og 3 alen høj. Disse ord virker påfaldende som sket under eller kort efter byggeriet. I hvert fald var kælderetagen, da denne grundplan blev tegnet, $i$ en miserabel tilstand. Det antyder årsagen til, at Gammelgårds hovedbygning sank i grus først i 1700-årene.

Efter grundplanerne, der har vist, hvordan slottet var indrettet efter udvidelsen, følger nu eksteriørtegningerne som vidnesbyrd om dets udseende efter 1665 


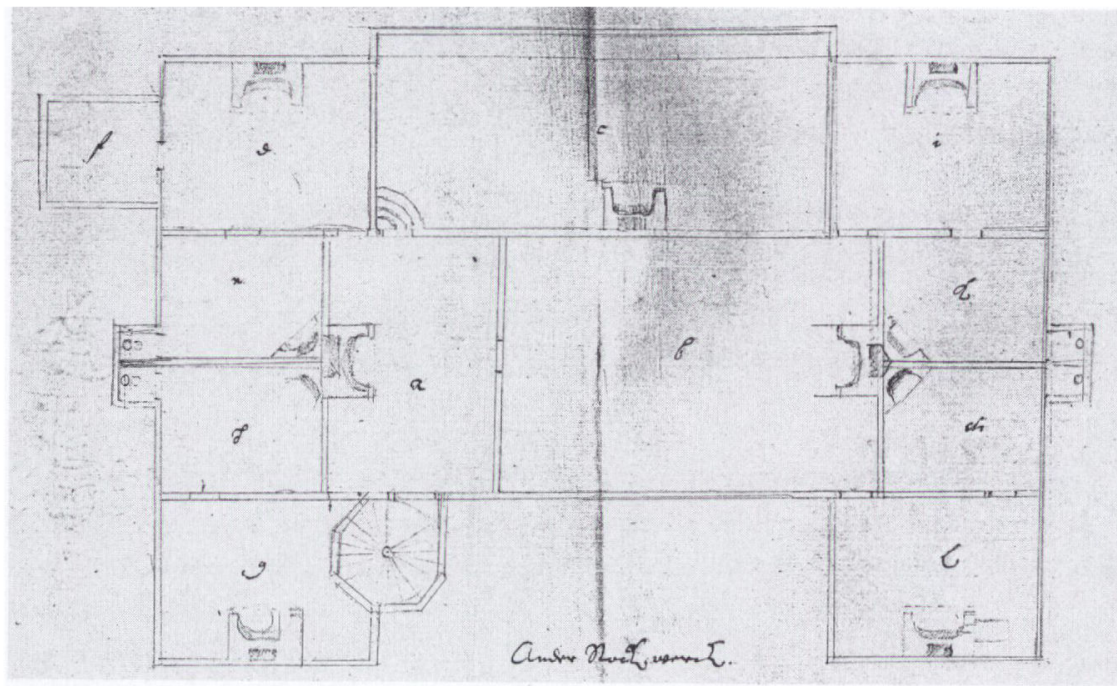

Fig. 7. Grundplan af 2. stokvark. Som foregående. Bogstavbetegnelser: A. Forgemak. B. Sal. C. Kirken. D. Gemak. E. Kammer. F. Kabinet. G. Kammer. H. Kammer. I. Gemak. K. Kammer. L. Gemak. M. Kammer.

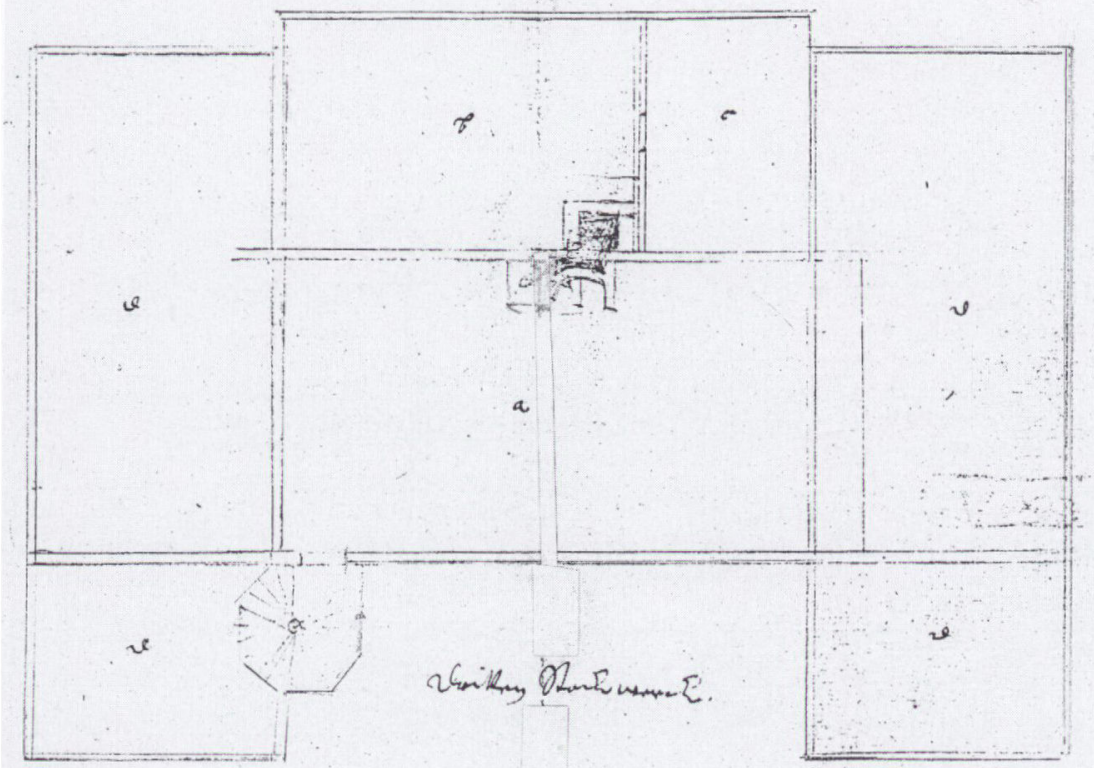

Fig. 8. Grundplan af 3. stokvark. Som foregaiende. 


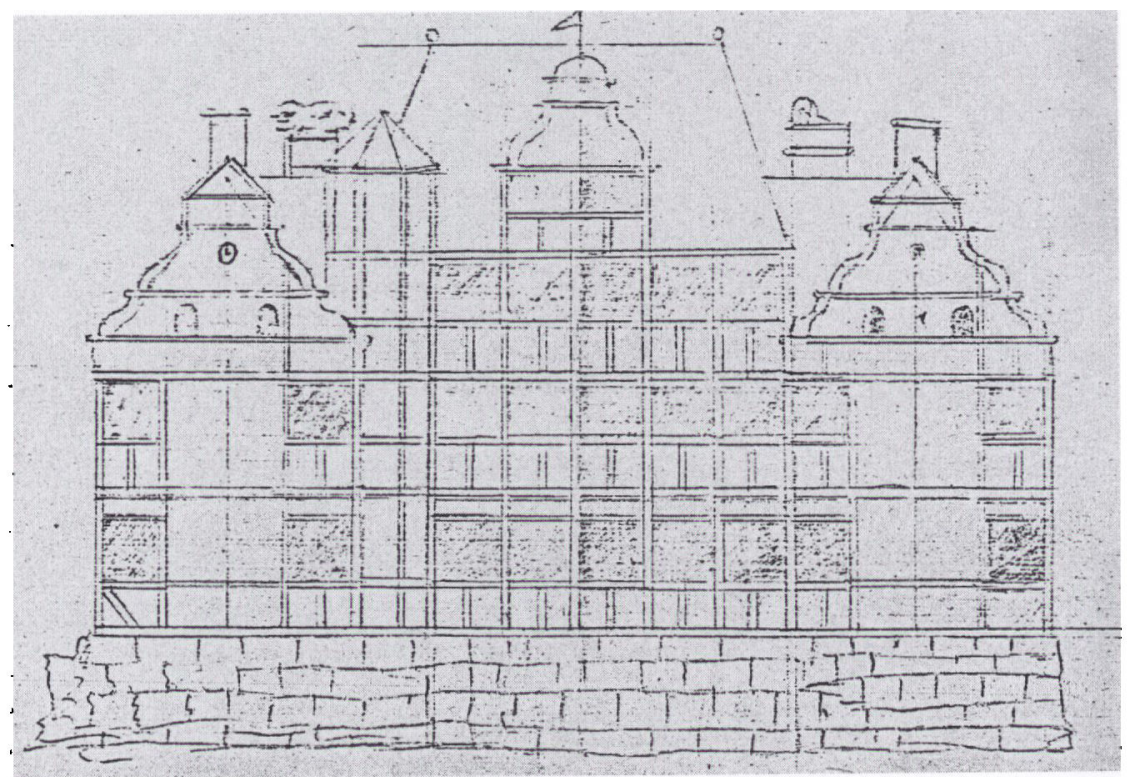

Fig. 9. Slotsfacaden mod nord efter 1665. Gengivelse af bygmestertegning.

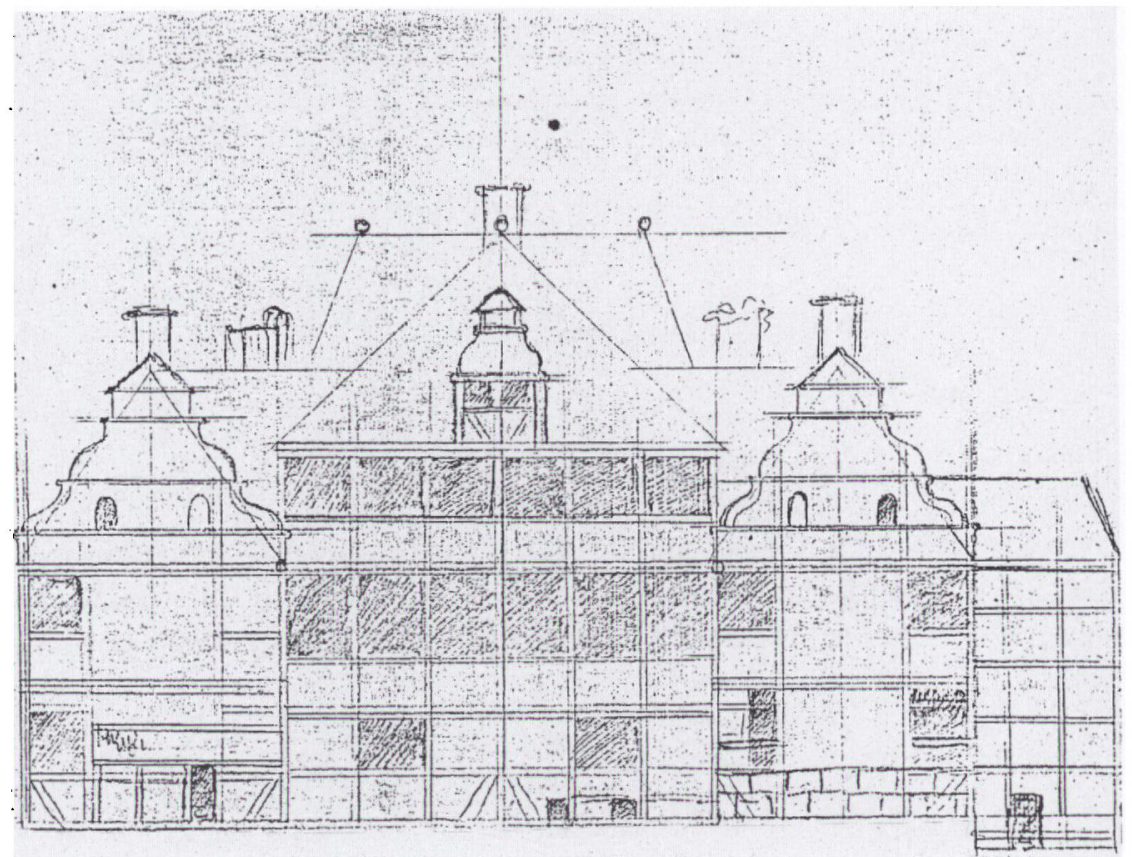

Fig. 10. Slottets sydfacade efter 1665. Gengivelse af bygmestertegning. 
fra de fire sider nord, syd, vest og øst. Først frontfacaden, betegnet "Vorne die Entre oder Norder Seiten« (fig.9). Hvad denne angår, er der sket det i forhold til tidligere, at midterbygningen er forhøjet med en etage i nøjagtig samme udformning som de to oprindelige stokværk. Samtidig er dens gavlkvist ført op til den nye tagrem i sin oprindelige skikkelse, formentlig ved benyttelse af de oprindelige svungne sandstenskarme og vandrette -bånd. Endvidere er indgangstårnet $i$ slotsgårdens sydøstre hjørne forhøjet tilsvarende med sin spidse taghætte, således at man fra den forhøjede vindeltrappe i tårnet kunne gå ind i det nye 3. stokværk. Endelig er der over hele midterbygningen - både den oprindelige og den tilbyggede - lagt et stort og højt, nyt valmtag.

I modsætning til nordfacaden, hvor bygningerne som for omkransede den nordre slotsgård, fremtræder sydfacaden helt anderledes end tidligere (fig. 10). Her er facademuren på den nye tilbygning over den tidligere slotsplads trukket et stykke ud over de to sidefløje-gavles byggelinie, som nævnt ovenfor under grundplanen (jvf. fig.6). Denne fremrykning af facademuren ses desværre ikke på den perspektivløse tegning. Derimod bemærkes nye skråbånd i de to midterste tavl forneden samt ligeledes et par små kældervinduer forneden $\mathrm{i}$ jordhøjde.

Ved første øjekast virker den her så dominante, fremskudte facademur ikke så meget anderledes end den nordre, men ser man nøjere til, er der åbenbare forskelle. Dens tre stokværk og vinduerne viser sig at være af forskellig højde. Særlig påfaldende er dette for stueetagens og førstesalens vedkommende. Medens den første er meget lavloftet og forsynet med blot to små vinduer, er den anden særdeles højloftet og udstyret med høje, tætsiddende vinduer $i$ alle fagene. Der er ved opførelsen sket en bevidst etageforskydning til fordel for den kirkesal, som hertuginden naturligvis har ønsket så højloftet og lys som muligt. Af samme grund er også 3. stokværk ret lavloftet.

Valmtaget har, set fra denne side, en tilsyneladende anden udformning end på nordsiden. Den mindre gavlkvist her er på grund af dens større afstand fra hovedtaget anbragt på et eget derfra udgående tag.

Hvad der er blevet mest skæmmet ved byggearbejdet i 1665 er utvivlsomt de to sidefløjes oprindelig så stilrene og smukke søndre gavlmure. Den østre ved formindskningen af de to gavlvinduer, hvoraf det inderste fremtræder som halveret, eftersom det herefter blot skulle give dagslys til den smalle korridor ved siden af gavlgemakket. Men meget værre med den vestre ved opførelsen opimod denne af det lange, smalle læskur for den nye bagdør ind til forvalterboligen. Af de på skuret synlige to tværbjælker foroven og fire stolper forneden må det fremgå, at denne tilbygning har haft skråt halvtag.

Til slut følger her nogle korte bemærkninger om forandringerne på de to sidefløjes ydermure (fig. 11-12). Hvad den vestre angår, da blev denne stående 


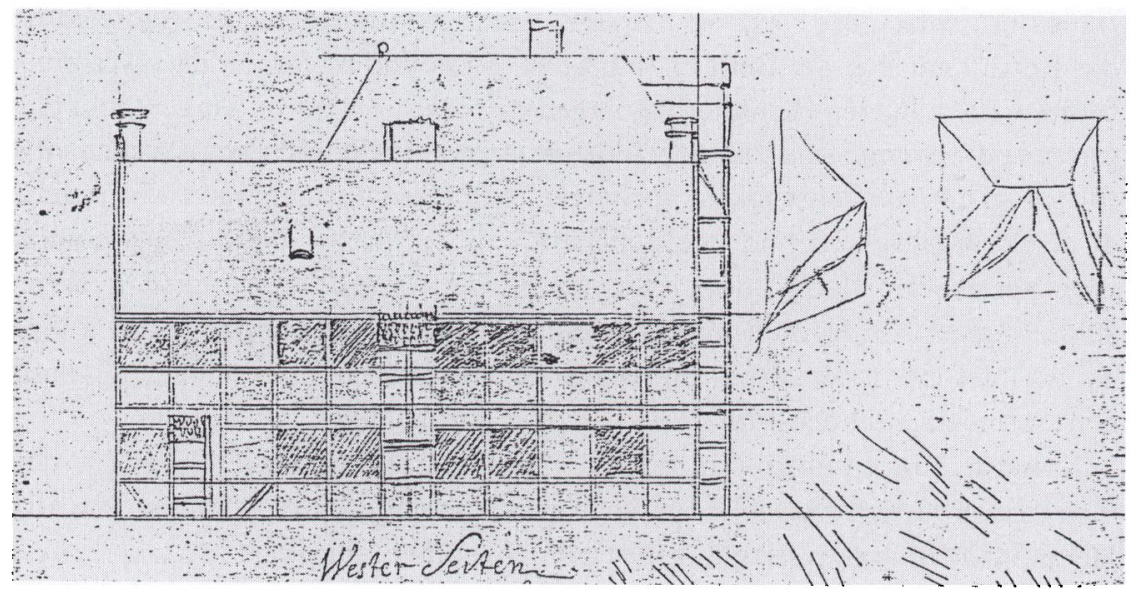

Fig. 11. Slottet set fra vest. Tegning af bygmesteren.

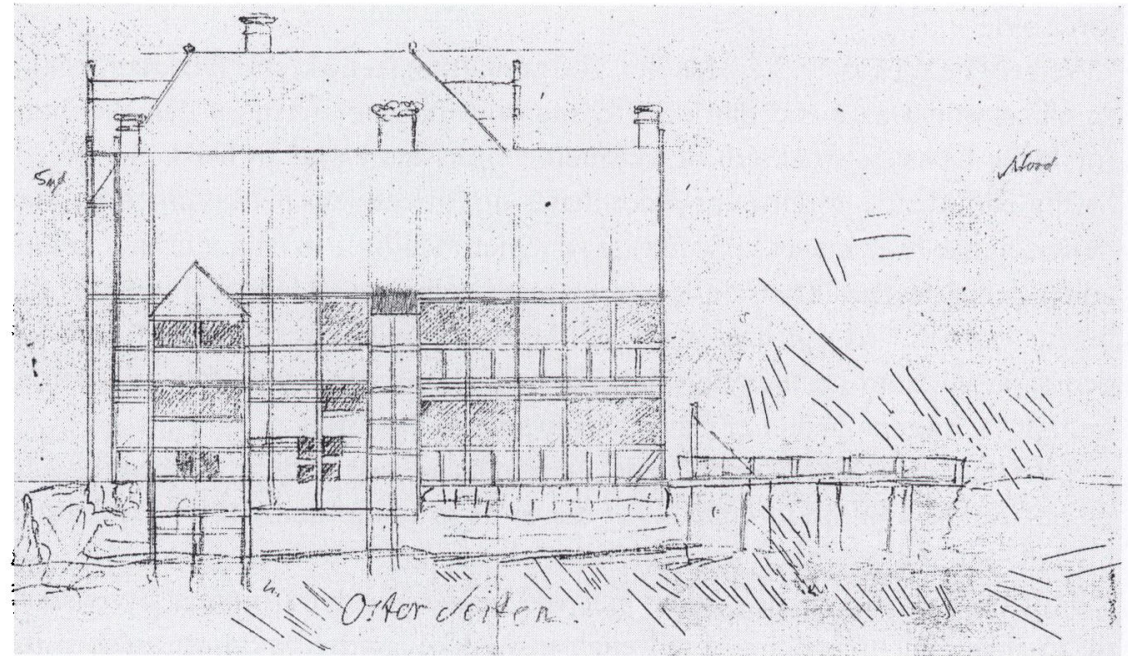

Fig. 12. Slottet set fra øst. Tegning som foregdiende. 
i sin oprindelige skikkelse, bortset fra indretningen af et særligt klosetrum i det nordre gavlgemak. Dette medførte en lille muret "pukkel« på vestmurens andet fag fra gavlen (se fig. 11).

Mere indgribende blev ændringerne på østmurens nordre halvdel som følge af opførelsen op mod denne af en næsten kvadratisk udbygning i to lave stokværk og med en lav kælder nederst. I denne udbygning blev der $\mathrm{i}$ begge dens etager indrettet såkaldte kabinetter ved gavlgemakkerne. Der må herfra have været en herlig udsigt over slottets park- og haveområder. Som det ses på fig. 12 blev denne udbygning bygget et godt stykke ud over voldgraven, til hvis bund de tre højstolper blev ført helt ned, - iøvrigt ganske som det var tilfældet ved den smallere klosetudbygnings to højstolper.

På begge disse tegninger forekommer et par bemærkelsesværdige skitser uden for selve bygningstegningen. På den første ses den oprindelige vindebro, der fra nord forte over voldgraven til den nordre slotsgård. Den hvilede på 4 brede støttepiller. Hejsetovet til den inderste broklap ses endnu på sin plads. På den anden ses på den tilsvarende plads to interessante skitser af tagformer. De må være tegnet her af bygmesteren selv og til anvisning for tømrerne om, hvorledes der skulle forholdes med hensyn til det nye brede valmtag og dets udløber til gavlkvisten mod syd. Ud fra dem må man roligt kunne fastslå tegningerne til at være udført i projekteringsfasen af eller i forbindelse med den udvidelse af slottet, som fandt sted i første halvdel af 1665 .

Ved det store byggeforetagende i 1665 må enkehertuginde Anna have fået opfyldt sine hede ønsker om en »egen kirke« $i$ slottet og om sikring af mere hjælp i dagliglivets fornødenheder ved at lade en forvalterfamilie få bolig i en lille del af det. Gennemførelsen af det omfattende byggeprojekt må imidlertid have været en kostbar affære, måske en af dråberne, der fik bægeret til at flyde over, da ulykken meldte sig. Den tid, hertuginden fik til at nyde sin alderdoms dage under mere betryggende forhold, blev kun af kort varighed. Det sønderborgske hertughus' dage var ved at være talte. I november 1667 blev lenet nemlig fradømt hendes søn, Christian Adolf, og fyrsterettighederne overgik da til kong Frederik III, medens hertugdømmets gods blev udlagt til kreditorerne. I sin nød må hertuginden da have søgt ly hos sin datter og svigersøn i Weimar, hvor hun ifølge kirkebogens beretning afgik ved døden i november 1668 .

Baggrunden for udarbejdelsen af dette indlæg er den, at det ved en længere brevveksling gennem foråret 1990 ikke lykkedes at overbevise min mangeårige gode ven og fittige fagkollega Peter Kr.Iversen i Aabenraa om berettigelsen af mit syn på Gammelgård slots bygningshistorie, der på afgørende punkter var forskellig fra det, han så langt tilbage som i 1949 havde fremført i et mindre afsnit af sin afhandling om herregårdens godshistorie. 
Både på grund af den længst forsvundne hovedbygnings kulturhistoriske værdi som arkitektonisk monument, og tilskyndet af overbevisningen om at for en historiker må det altid være vigtigt at finde frem til, hvordan en sag $i$ virkeligheden har været (jvf. Leopold von Ranke's kildekritiske fordring "wie es eigentlig gewesen«), kunne jeg ikke lade være med at foretage en nærmere undersøgelse.

Da jeg først nu - i sommeren 1991 - er blevet klar over, at man end ikke kender det omtalte voldsteds og bygningsværks nøjagtige beliggenhed, vil jeg til allersidst udtale ønsket om, at der må blive iværksat en grundig bygningsarkæologisk efterforskning på Gammelgård. En sådan har i mange tilfælde givet gode og overraskende resultater - på Als f.eks. ved Østerholm.

\section{NOTER OG HENVISNINGER}

1. SJy. Årb. 1949, 92-142.

2. Landsarkivet i Aabenraa, Sønderborg amtsarkiv 192, 1669-1774, Sag vedr. Gammelgår II.

3. Jørgen Paulsen: Et landkort over Als og Sundeved 1655. Fra Als og Sundeved, bd.68, 1990, 577.

4. Jørgen Steen Jensen: Hertug Hans den Yngre, 1971, 50-51 og 170, note 9. Beskrivelse og gengivelse af grundplan.

5. Ifølge en synsforretning fra 1728 var dette fundament 4 lybske alen højt og 41 langt. Se: Peter Kr. Iversen, s. 101.

6. Dokker er betegnelsen for de korte, lodrette tømmerstykker i en bindingsvarksvæg; skråbånd for stykkerne $\mathrm{i}$ hjørner for at stabilisere bygningskonstruktionen.

7. Omtrentlige mål: voldstedet $30 \times 20 \mathrm{~m}=600 \mathrm{~m}^{2}$; bebygget grundareal: $27 \times 18 \mathrm{~m}=486 \mathrm{~m}^{2}$; boligareal $\mathrm{i}$ alt $520 \mathrm{~m}^{2}$; de to slotsgårde: $110 \mathrm{~m}^{2}$ hver. Ved til- og ombygningen i $1665 \mathrm{blev}$ boligarealet foreget med ca. $300 \mathrm{~m}^{1} 2$.

8. Christiane Elisabeth (1638-79), gift 1656 med hertug Johan Ernst af Sachsen. Weimar.

9. Enkehertugindens gavmildhed mod netop de to nævnte kirker skyldes, at $i$ de to sogne lå Gammelgårds fleste gårde og kảd, nemlig i Tandslet hhv. 26 og 23, i Asserballe 23 og 33.

10. SJy.Årb., 1949, 103, note 3.

11. Danmarks Kirker, III, 1961, 2533 og Trap Danmark, 3, 1964, 1267.

12. Se H.P.Clausen og Jørgen Paulsen: Augustenborgerne, 1980, 139.

13. Se Otto Norn: Østerholm Slotsruin på Als. Fra Nationalmuseets Arbejdsmark, 1956, 103-114. 